\title{
Development of new incretin drugs: Promising therapies
}

\author{
K. Kaur, C.S. Gautam
}

Department of Pharmacology Government Medical College and Hospital Chandigarh-160032.

Received: 17.8.2005

Revised: 11.11.2005

Accepted: 6.12.2005

Correspondence to: Kirandeep Kaur 612 ,Phase 2,

Mohali-160052. Punjab Email: kiransondhi@gmail.com

\begin{abstract}
New agents are being added to the armamentarium of drugs used for the treatment of diabetes mellitus. Today, extensive research is being conducted on incretin hormones. Important among them are, Glucagon like peptide-1 (GLP-1) and Glucose dependent insulinotropic peptide (GIP). The gastrointestinal tract secretes these hormones in response to the ingestion of nutrients. These hormones increase secretion of insulin, decrease secretion of glucagon, decrease gastric emptying time (only by GLP-1). In addition, they decrease body weight and prevent development of resistance to insulin. They are rapidly degraded by dipeptidyl peptidase (DPP-IV) enzyme. Analogs of GLP-1 and GIP and inhibitors of DPP-IV are being synthesised. Exenatide, a synthetic analog of GLP-1, has recently been approved by the FDA, USA for use in patients with type 2 diabetes who have sub optimal control despite treatment with metformin and / or a sulfonylurea. Other GLP-1 analogs under clinical trial are: NN2211, CJC1131, and Albugon. No analog of GIP and inhibitor of DPP-IV have been approved by the FDA for clinical use till now. Vildagliptin, an inhibitor of DPP-IV, is under phase 2 clinical trials. The incidence of hypoglycemia is less with these incretin mimetics and inhibitors of DPP-IV. Minimal gastrointestinal side effects are seen. Analogs of GLP-1 have to be given subcutaneously, while inhibitors of DPP-IV can be given orally. There is a need to synthesise long acting analogs of GLP-1 and selective inhibitors of DPP-IV.
\end{abstract}

KEY WORDS: Diabetes mellitus, GLP-1, GIP, DPP-IV.

\section{Introduction}

Patients with type 2 diabetes require a stepwise management approach. Initial management involves lifestyle modifications and treatment with antihyperglycemic agents. If targets are not achieved, then a combination therapy of oral agents and insulin is used. However, oral antihyperglycemic agents available now have not been shown to alter the progressive $\beta$ cell failure, and the current combination therapy for type 2 diabetes may be associated with an increased risk of adverse effects, such as, hypoglycemia and gain in bodyweight. ${ }^{[1]}$

To overcome these problems, new pharmacological agents targeting the incretin hormones are being synthesised.Incretin hormones are released from gastrointestinal tract in response to dietary nutrients and then, they stimulate secretion of insulin. This review is focused on the role of incretins in type 2 diabetes mellitus.

The incretin effect

Incretins are hormones released by nutrients from the gastrointestinal tract. They amplify release of insulin induced by glucose. By raising circulating levels of incretin, oral glucose provokes a higher response of insulin than intravenous glucose. It is known that insulin response to oral glucose exceeds that measured after intravenous administration of equivalent amounts of glucose. ${ }^{[2],{ }^{[3]}}$ It has been shown that the incretin effect is responsible for about 50-70\% of insulin response to oral glucose in healthy individuals. ${ }^{[4], ~[5]}$ Many postprandial hormones have incretin-like activity, but glucagon like peptide1 (GLP-1) and glucose dependent insulinotropic polypeptide, also known as gastric inhibitory peptide (GIP), are the most important ones in the management of type 2 diabetes mellitus. In patients with type 2 diabetes, the incretin effect is mainly decreased because of loss of the second phase of secretion of insulin that is regulated by GIP and less secretion of GLP-1.

The incretin hormones: GIP and GLP-1

GIP and GLP-1 are members of the glucagon peptide super family and share considerable amino acid homology. Both are rapidly inactivated by amino peptidase dipeptidyl peptidase IV (DPP -IV). ${ }^{[6]}$

\section{Glucose dependent insulinotropic peptide}

GIP is a single 42 amino acid peptide encoded within a larger 153 amino acid precursor. ${ }^{[7]}$ The enteroendocrine K cells 
in the duodenum and the proximal part of the jejunum secrete it. The main stimulant for secretion of GIP is ingestion of meals rich in carbohydrate and lipid. Following ingestion, circulating plasma levels of GIP increase $10-20$ fold. Secretion of GIP reaches peak concentration within 15-30 min of ingestion of oral glucose or lipids, even before the nutrients are absorbed into the gut. ${ }^{[8],[9]}$ This suggests a potential role of other influences in secretion of GIP. The half-life of intact GIP is approximately 7 and 5 min in non-diabetic and diabetic persons, respectively. ${ }^{[10]}$

Following secretion into the circulation, intact GIP (1-42 amide) is cleaved at the amino terminus by DPP-IV, resulting in the formation of the inactive truncated GIP (3-42 amide). This lacks incretin activity and may even act as an antagonist of GIP at its receptor. ${ }^{[11]}$

\section{Action of GIP}

Initially, it was thought that GIP inhibits secretion of gastric acid. Therefore, it was named 'gastric inhibitory peptide'. However, studies on humans have failed to demonstrate any significant role of physiologic GIP on secretion of gastric acid. ${ }^{[12]}$

The incretin effect of GIP was first appreciated in the 1970s. ${ }^{113], ~[14] ~ T h e ~ p h y s i o l o g i c ~ e f f e c t s ~ o f ~ G I P ~ h a v e ~ b e e n ~ e l u c i d a t e d ~}$ using receptor antagonists of GIP, peptide antagonists of GIP, and receptor knockout mice of GIP. Blocking the binding of GIP to its receptor leads to an attenuated glucose dependent secretion of insulin. This is in response to the loading of oral glucose in rats and mice used in experiments. ${ }^{[15]}$

Administration of antagonists of GIP markedly reduces the postprandial release of insulin in rats. ${ }^{[16]}$ Ehali and colleagues demonstrated that infusion of GIP results in secretion of insulin only in the presence of elevated concentration of glucose. ${ }^{[17]}$ It was also demonstrated that GIP is not glucagonotropic in healthy humans in euglycemic and hyperglycemic conditions. The effect of endogenously released GIP appears to be an important mechanism of postprandial secretion of insulin and does not appear to play a role during fasting.

GIP stimulates proliferation of beta cell and survival of cells in INS-1 islet cell-line studies. ${ }^{[18-\mid 20]}$ In patients with type 2 diabetes, secretion of GIP is preserved, compared with individuals without diabetes. ${ }^{[21,[22]}$ Infusion of GIP exhibits a marked reduction of insulinotropic activity in patients with type 2 diabetes. In other words, in these patients, there is a decreased response of insulin secretion to the infusion of GIP, compared with non-diabetic control subjects. ${ }^{\mid 23]}$ The GIP defect in insulin secretion is most pronounced in the late phase of secretion of insulin. ${ }^{24]}$

GIP plays a role in the metabolism of lipid by stimulating the activity of lipoprotein lipase, inducing the incorporation of fatty acids into adipose tissue, and stimulating the synthesis of fatty acid. ${ }^{[25]}$ The role of GIP in obesity is also being studied. It has been observed that GIP receptor knock out mice are protected from obesity induced by high fat diet. However, elimination of the effect of endogenous GIP may impair the postprandial secretion of insulin and, therefore, severely disturb glucose homeostasis. ${ }^{\mid 26]}$

\section{Glucagon like peptide-1}

GLP-1, a product of the glucagon gene was first identified in the early 1980s. ${ }^{[27]}$ GLP-1 is a 30/31 amino acid peptide. It is derived from a larger proglucagon precursor, which also releases other peptides like glucagon, GLP-2, oxyntomodulin, and glicentin. ${ }^{[28]}$ Like GIP, the GLP-1 receptors are widely expressed in pancreatic islets, brain, heart, kidney, and gastrointestinal tract. ${ }^{[29]}$ Enteroendocrine L- cells are located predominantly in the ileum, and the colon secrete them.

Biologically active GLP-1 is of two major types, GLP-1 [737] and GLP-1 [7-36] amide, which differ by a single amino acid. The majority of the circulating GLP-1 is GLP-1 [7-36] amide. Both GLP-1 [7-37] and GLP-1 [7-36] amides are equipotent and have similar activities. Secretion of GLP-1 is controlled by both neural and endocrine cells. It is caused by entry of nutrients in the proximal GIT as well as by the subsequent direct contact of open type-L- cells with nutrients that have been digested. ${ }^{[21]}$ Plasma levels of GLP-1 increase rapidly within minutes of ingestion and are highly correlated with the release of insulin. ${ }^{[30 \mid,[31]}$ DPP-IV rapidly cleaves GLP-1 to its truncated inactive metabolite. These peptides have a short half-life of 2 min in both non-diabetic and diabetic patients. ${ }^{[32]}$ Like GIP, GLP-1 enhances secretion of insulin only in the presence of elevated concentration of glucose.

\section{Action of $G L P-1$}

Most of the actions of GLP-1 observed in animals have also been demonstrated in human studies. GLP-1 is responsible for a significant part of the response of insulin to oral glucose. ${ }^{\mid 211}$ It is not only an insulinotropic hormone, but also inhibits secretion of glucagon in a glucose dependent manner. ${ }^{|27|}$ Suppression of glucagon does not occur at hypoglycemic concentrations of plasma glucose, but requires the presence of euglycemia or hyperglycemia. ${ }^{[33]} \mathrm{GLP}-1$ leads to expansion of the mass of $B$ cell via islet cell neogenesis. ${ }^{[34|,| 35]}$ It has also been shown that GLP-1 can induce the differentiation of two pancreatic ductile cell lines, ARIP (in rats) and PANC-1 (in humans) into insulin producing and insulin secreting cells. ${ }^{[36]}$ It has been seen that improvement in tolerance to glucose by GLP-1 is maintained for a long time. This suggests that these effects cannot be simply explained as caused by the modulation of preformed insulin secretion, but must involve more substantial modifications in the functional activity of $\beta$ cells. It has been observed that GLP-1 drastically reduces the $B$ cell apoptosis. ${ }^{[37]}$ Farilla et al observed that improvement in the viability of cell can cause a significant amelioration of the function of islet cell. ${ }^{[38 \mid}$ In rodents, acute intracerebroventricular injection of GLP-1 or receptor agonists of GLP-1 results in reduction of food intake. ${ }^{[27]}$ Some studies have shown that peripheral administration as well as chronic intracerebroventricular administration of GLP-1 receptor agonist result in weight loss. ${ }^{[39],[40]}$ Such results have been observed in some, but not all human studies. ${ }^{[41-\mid 45]}$ This reduction of food intake may be due to reduced gastric emptying rate. In a prospective, placebo controlled study by Zander et al, 20 patients with type 2 diabetes received GLP-1 or saline by continuous subcutaneous infusion for 6 weeks. Patients receiving GLP-1 had significant reduction in weight by $1.9 \mathrm{~kg}$, inhibition of gastric emptying, and reduction in appetite. ${ }^{[46]}$ In contrast to GIP, these effects are comparable in diabetics and non-diabetics. 
Agonists of GLP-1 have neural actions. They act on the brain receptors of GLP-1. In addition to the circulating GLP-1, which enters the brain in the periventricular areas, GLP-1 is also synthesised in the nucleus solitarius of the brain stem. ${ }^{[47]}$ CNS effects of GLP-1 include regulation of food intake and body weight. GLP-1 is also a mediator of multiple stress responses. When infused into the lateral ventricle, it potentiates the release of corticotropin releasing hormone. It exhibits antiapoptotic and neurotrophic effects in neuronal cells, similar to its trophic actions in B cells. The effects of GLP-1 are similar to those of nerve growth factor. GLP-1 and receptor agonists of GLP-1 have shown protective effects that are dependent on concentration, with decreased amyloid B protein 1-40 levels. This suggests a role for GLP-1 and its agonists in the treatment of Alzheimer's disease. ${ }^{[47]}$

In contrast to GIP, GLP-1 levels were shown to be reduced in obese patients with type 2 diabetes, who were resistant to insulin. This particularly occurred during the second hour after the nutrient stimulus. ${ }^{[22]}$ Infusion studies with GLP-1 in subjects with type 2 diabetes show a pronounced and preserved glucose dependent response of insulin to exogenously administered GLP-1. ${ }^{|48|}$

Together, the two hormones appear to act in an additive manner. Therefore, when GIP and GLP-1 infusions (that separately provide similar responses of insulin) were combined, the resulting response amounted to approximately the sum of the individual responses. ${ }^{\mid 49]}$ Recently, mice with a double knockout of the GIP and GLP-1 receptors have been generated. ${ }^{[50], ~[51]}$ The results obtained in these animals are consistent with the additive effect of the two hormones on tolerance to glucose. The double knockout animals did not develop fasting hyperglycemia in any of the studies, and their sensitivity to insulin was normal. Interestingly, the potent receptor agonist of GLP-1, exendin-4, which in control animals profoundly lowered blood glucose, had no effect in the double knockouts, suggesting that it acts exclusively via incretin receptors. Furthermore, valine pyrrolidide and SYR 106124 (inhibitors of DPP IV), which lower blood glucose and improve tolerance to glucose in both GLP-1 and GIP single receptor knockout mice, had no effects in the double knockouts. This suggests that the effects of these inhibitors are exerted mainly by enhancing survival of GIP and GLP-1, without important involvement of other substrates. ${ }^{[52]}$

\section{Current status of drugs under development}

Today, there are two approaches for utilising the antihyperglycemic potential of incretin hormones. They involve the use of incretin mimetics and inhibitors of DPP-IV, respectively.

\section{Incretin mimetics}

Incretins enhance insulin secretion that is glucose dependent and exhibit other antihyperglycemic actions following their release into circulation from the gut, in response to intake of food.

Analogs of GIP

GIP has insulinotropic action. It stimulates B cell proliferation and inhibits apoptosis in islet cell lines. ${ }^{[18 \mid-20]}$ However, there are certain limitations in using GIP as a therapeutic agent. GIP has a short half life in the circulation due to rapid cleavage and degradation by enzyme DPP-IV. ${ }^{[53]}$ The cleaved metabolite is not only inactive, but may also function as a receptor antagonist of GIP. ${ }^{[11]}$

The response to GIP infusion in subjects with type 2 diabetes is controversial. According to some studies, exogenous administration of GIP is comparatively less insulinotropic in obese, diabetic rodents. ${ }^{|2|}$ Some other studies on animals have shown the insulinotropic and glucose lowering properties in both normal and diabetic rodents. ${ }^{[54 \mid-[56]}$ A trial on humans with type 2 diabetes has shown that stimulation of secretion of insulin by GIP is stronger after its bolus administration than during continuous infusion. According to this trial, the relative sensitivity of secretion of insulin to a bolus administration of GIP is almost preserved. ${ }^{[57]}$

Several analogs of GIP modified at the Tyr-1 position, with resistance to degradation by DPP-IV, have been developed..$^{[58]}$ Another novel, N-terminally protected, fatty acid derivatised analog of GIP, N-AcGIP (LysPAL(37)), has been studied in obese, diabetic $(\mathrm{ob} / \mathrm{ob})$ mice. Once daily injections of N-AcGIP (LysPAL (37)) in ob/ob mice over a 14-day period significantly decreased plasma glucose and glycated hemoglobin and improved tolerance to glucose, compared with saline or native administration of GIP. Plasma insulin and pancreatic insulin content were significantly increased by N-AcGIP(LysPAL(37)). ${ }^{[59]}$ Therapeutic strategies based on either augmenting or antagonizing GIP action are far from being established as the future therapy for Type2 diabetes or obesity.

\section{Analogs of GLP-1}

The second incretin hormone, GLP-1, has already been exploited as a target drug. Several studies with infusion of GLP-1 in patients with type 2 diabetes have consistently shown improvements in glucose dependent secretion of insulin, reduction of glucose level, postprandial reduction of glucagon, and improvements in $\beta$ cell function as well as gastric emptying. Although single or repeated subcutaneous injections of native GLP-1 decrease blood glucose in humans, this effect is transient and lasts for $1-2 \mathrm{~h}$ after injection of peptide. ${ }^{[60]}$ Maximum benefit can be achieved only if the response of incretin is for a longer period.

Exendin-4 is a naturally occurring 39- amino acid receptor agonist of GLP-1, isolated from the salivary gland venom of the lizard, Heloderma suspectum. ${ }^{[61]}$ Exendin-4 exhibits 53\% amino acid identity to mammalian GLP-1 ${ }^{[61],[62]}$ and binds to and activates receptor of GLP-1. Exendin-4 is highly resistant to the proteolytic activity of DPP-IV and exhibits a longer duration of action. The FDA has recently approved exenatide, a synthetic peptide of natural exendin-4 for use in patients with type 2 diabetes who have suboptimal glycemic control, despite treatment with metformin and/or sulfonylureas . ${ }^{[63]}$

In a trial, 109 patients with type 2 diabetes who demonstrated inadequate glycemic control with sulfonylureas and/or metformin and had an $\mathrm{HbA}_{1 \mathrm{c}}>8 \%$ were randomised to receive either $0.08 \mu \mathrm{g} / \mathrm{kg}$ exenatide subcutaneously 2 to 3 times daily or placebo. After 28 days of treatment, there was a significant reduction in mean $\mathrm{HbA}_{1 \mathrm{c}}$ compared with placebo. No significant change was observed in body weight or serum lipids. The most common adverse effect was nausea. ${ }^{[64]}$ 
Several other studies with higher doses (5 and10 $\mu \mathrm{g} / \mathrm{kg}$ ) have shown significant decrease in $\mathrm{HbA}_{1 \mathrm{c}}$ levels. Nausea, diarrhoea, vomiting, and hypoglycemia were the common adverse effects. ${ }^{[65]}$ In a trial of patients with type 2 diabetes who had failed to achieve glycemic control with maximally effective metformin doses, exenatide reduced $\mathrm{HbA}_{1 \mathrm{c}}$ with no weight gain and no increased incidence of hypoglycemia. ${ }^{[66]}$ In another trial, exenatide significantly reduced $\mathrm{HbA}_{1 \mathrm{c}}$ in patients with type 2 diabetes who were unable to achieve adequate glycemic control with maximal effective doses of combined metformin-sulfonylurea therapy. The improvement in glycemic control was not associated with weight gain and treatment was generally well tolerated. ${ }^{[67]}$ In all these trials, the common adverse effects related to treatment were hypoglycemia, nausea, vomiting, diarrhoea, jitteriness, dizziness, and headache. ${ }^{[65]-[67]}$

It has been observed that gradual escalation of dose of exenatide successfully reduces the proportion of subjects experiencing nausea and vomiting that limit the dose. There is no loss of glucoregulatory activity. ${ }^{[68]}$ Exenatide should be initiated at a dosage of $5 \mu \mathrm{g}$ twice a day. The dose can be increased to $10 \mu \mathrm{g}$ twice daily, after one month of treatment, depending on the clinical response. ${ }^{[1]}$

Another long acting formulation of exenatide is being tried on animals so as to minimise the side effects and the difficulty of repeated injections. A single dose of exenatide-LAR (long acting release) enhanced the glucose control for 28 days in the ZDF rat model of type 2 diabetes. This suggests that tachyphylaxis is unlikely to be a feature of exenatide-LAR preparations and supports further clinical exploration. ${ }^{[69]}$

Another analog of GLP-1 under clinical investigation is NN2211 (liraglutide). It has a 97\% homology with GLP-1. It is released slowly from the injection site and has a fatty acid binding moiety leading to albumin binding. ${ }^{[70]}$ After a single injection, (the half-life of liraglutide is 11-15 h) there is a decrease in glucagon and an increase in insulin levels. A single daily dose improves the glucose profile within $24 \mathrm{~h}$ in type 2 diabetics. ${ }^{[11 \mid}$ Phase 1 study with subcutaneous injections of single escalating doses of liraglutide in healthy male subjects has shown increase in secretion of insulin during an intravenous glucose tolerance test. Minor side effects reported were headache, dizziness, nausea and vomiting. ${ }^{\text {.72] }}$

Another analog of GLP-1, CJC-1131, is composed of a DAla8-substituted GLP-1 molecule with a linker and a reactive moiety attached to the COOH-terminus. After injection in vivo, this molecule conjugates covalently to Lys34 of albumin and acquires the half-life of albumin. ${ }^{[73 \mid}$ Studies on rodents have demonstrated the insulinotropic activities of CJC-113173 which currently is in phase 2 clinical trials. ${ }^{\text {174] }}$ Twice daily administration of CJC-1131 to db/db mice significantly reduced glycemic excursion following oral and IP glucose challenge $(\mathrm{P}<0.05)$, but did not significantly lower body weight during the 4-week study period. CJC-1131 increased the levels of pancreatic proinsulin mRNA transcripts, percent area of islet, and number of bromodeoxyuridine-positive islet cells. ${ }^{[73]}$ CJC1131 covalently couples with HSA (human serum albumin) after parenteral administration and liraglutide binds to albumin in a noncovalent dissociable manner. Another agent, albugon, is a fusion protein consisting of DPP-IV resistant analog of
GLP-1, which is covalently bound to human albumin. Therefore, no "free" GLP-1 is associated with administration of albugon in vivo. Albugon activates the cloned GLP-1R, but with a reduced affinity relative to the potent GLP-1R agonist exendin-4. Given the intense interest in the development of long-acting agonists of GLP-1R for the treatment of type 2 diabetes, the biological properties and mechanisms of action of GLP-1-albumin derivative merit further investigation. ${ }^{\text {[5] }}$

\section{Inhibitors of DPP-IV}

As GIP and GLP-1 are cleaved by DPP-IV, inhibition of this enzyme can also increase the levels of incretin hormones. Many studies on animals ${ }^{|76|}$ and humans ${ }^{|77|}$ have shown prolongation of GIP and GLP-1 activity and improved glycemic control with inhibitors of DPP-IV.

Many inhibitors of DPP-IV are under clinical development. Vildagliptin (LAF237), a second-generation drug is under phase III trials. In a one-year trial of 107 metformin treated patients with type 2 diabetes, 56 received LAF237 (50 mg daily) plus metformin (mean $1.8 \mathrm{~g}$ daily) and 51 received metformin plus placebo. At three months, $\mathrm{HbA}_{1 \mathrm{c}}$ was $0.7 \%$ lower with a decrease in fasting and postprandial glucose of 22 and $40 \mathrm{mg} /$ dl, respectively, in the vildagliptin group. After a follow-up of 1 year, $\mathrm{HbA}_{1 \mathrm{c}}$ remained stable in the test group, while in the placebo group the $\mathrm{HbA}_{1 \mathrm{c}}$ increased to $8.4 \%$, and there was no effect on weight. ${ }^{.46]}$ Vildagliptin improves $\beta$-cell function in diabetic patients by increasing secretory tone of insulin. ${ }^{\text {[8] }}$

A novel series of B-amino amides incorporating fused heterocycles, that is, triazolopiperazines, were synthesised and evaluated as inhibitors of dipeptidyl peptidase IV (DPP-IV) for the treatment of type 2 diabetes. (2R)-4-0x0-4-[3(trifluoromethyl)-5,6-dihydro[1,2,4]triazolo[4,3-a]pyrazin$7(8 \mathrm{H})$-yl]-1-(2,4,5-trifluorophenyl)butan-2-amine (1) is a potent, orally active inhibitor of DPP-IV $\left(\mathrm{IC}_{50}=18 \mathrm{nM}\right)$ with excellent selectivity over other proline-selective peptidases, oral bioavailability in preclinical species, and in vivo efficacy in animal models. MK-0431, the phosphate salt of this compound has been selected for development as a potential new treatment for type 2 diabetes. ${ }^{[79]}$ Many other compounds are being developed. Oral metformin also inhibits DPP IV activity in type 2 diabetic patients, suggesting that the drug may have potential for future combination therapy with incretin hormones. ${ }^{[80]}$

Drawbacks of inhibitors of DPP-IV: There is limitation to the development of inhibitors of DPP-IV as drugs. DPP-IV enzyme exhibits catalytic activity against a broad range of peptides, for example, neuropeptide $\mathrm{Y}$, endomorphin and peptide YY. Therefore, selective inhibition is required. Furthermore, DPP-IV, also known as the lymphocyte cell surface transmembrane -signaling molecule CD26, is activated by external stimuli and modulates T-cell activation, producing pleiotropic effects in experimental inflammatory and neoplastic disorders. ${ }^{\mid 81], ~[82]}$ Global genetic inactivation of CD26 in mice is associated with subtle, but detectable abnormalities in the secretion of cytokine and immunoglobulin after stimulation of mitogen. ${ }^{[33]}$ Highly selective inhibitors of DPP-IV are under clinical development.

The advantage of inhibitors of DPP-IV over agonists of GLP1 is that they can be given orally, while the latter have to be 
Table 1

Characteristics of inhibitors of DPP-IV and agonists of GLP-1R

\begin{tabular}{ll}
\hline Inhibitors of DPP-IV & Agonists of GLP-1R \\
\hline Orally available & $\begin{array}{l}\text { Injectable } \\
\text { Multiple targets }\end{array}$ \\
GLP-1 PK favorable & $\begin{array}{l}\text { Higher levels of GLP-1 } \\
\text { achievable, but narrow PK profile }\end{array}$ \\
Short- versus long-acting & Longer acting-days to weeks \\
Less potent agents & More potent glucose lowering \\
Drug overdose nontoxic & Drug overdose problematic \\
No central nervous system & Nausea and vomiting \\
side effects & \\
Less defined side effect profile & Well-described and tolerable \\
& side effect profile
\end{tabular}

GPCR, G protein-coupled receptor; PK, pharmacokinetic. "Reprinted with permission from The American Diabetes Association. Copyright @2003 American Diabetes Association. From Diabetes Care,Vol.26, 2003;2929-2940."

administered subcutaneously ${ }^{[84]}$ However, the side effects of inhibitors of DPP-IV are not known now.[Table 1] In addition, the effect of inhibitors of DPP-IV will be less than receptor agonists of GLP-1 in type 2 diabetic patients. This is because the circulating levels of GLP-1, stimulated by meals, are reduced in such patients.

\section{Conclusion}

With the approval of exenatide for clinical use, there is increasing interest in the development of drugs targeting the incretins, for example, secretagogues of GLP-1 or GLP-1 receptor activators. The availability of this new group of agents may be helpful for patients in whom it has been difficult to reach the target levels with the available agents. The lesser incidence of hypoglycemia coupled with no weight gain gives this group of drugs an advantage over the drugs that are currently available. The disadvantage of frequent dosing schedule of exenatide may be overcome with the availability of longer acting agents. These drugs provide a novel and much needed expansion of the therapeutic options available and lend momentum to the continued effort to advance our understanding and treatment of this complex disease.

\section{References}

1. Parkes DG, Pittner R, Jodka C, Smith P, Young A. Insulinotropic actions of exendin-4 and glucagon-like peptide-1 in vivo and in vitro. Metabolism 2001; 50:583-9.

2. Elrick H, Stimmler L, Hlad CJ, Arai Y. Plasma insulin responses to oral and intravenous glucose administration. J Clin Endocrinol Metab 1964;24:107682.

3. McIntyre N, Holdsworth CD, Turner DS. Intestinal factors in the control of insulin secretion. J Clin Endocrinol Metab 1965;25:1317-24.

4. Nauck MA, Homberger E, Siegel EG, Allen RC, Eaton RP, Ebert R, et al. Incretin effects of increasing glucose loads in man calculated from venous insulin and C-peptide responses. J Clin Endocrinol Metab 1986;63:492-8.

5. Nauck M, Stockmann F, Ebert R, Creutzfeldt W. Reduced incretin effect in type 2 (non-insulin-dependent) diabetes. Diabetologia 1986;29:46-52.

6. Kieffer $\mathrm{TJ}$, McIntosh $\mathrm{CH}$, Pederson RA. Degradation of glucose-dependent insulinotropic polypeptide and truncated glucagon-like peptide 1 in vitro and in vivo by dipeptidyl peptidase IV. Endocrinology 1995;136:3585-96.

7. Takeda J, Seino Y, Tanaka K, Fukumoto H, Kayano T, Takahashi H, et al. Sequence of an intestinal cDNA encoding human gastric inhibitory polypeptide precursor. Proc Natl Acad Sci USA 1987;84:7005-8.

8. Cataland S, Crockett SE, Brown JC, Mazzaferri EL. Gastric inhibitory polypeptide (GIP) stimulation by oral glucose in man. J Clin Endocrinol Metab 1974:41:260-5.

9. Falko JM, Crockett SE, Cataland S, Mazzaferri EL. Gastric Inhibitory Polypeptide (GIP) stimulation by fat ingestion in man. J Clin Endocrinol Metab 1975; $41: 260-5$

10. Deacon CF, Nauck MA, Meier J, Hucking K, Holst JJ. Degradation of endogenous and exogenous gastric inhibitory polypeptide in healthy and in type 2 diabetic subjects as revealed using a new assay for the intact peptide. J Clin Endocrinol Metab 2000;85:3575-81.

11. Meier JJ, Nauck MA, Schmidt WE, Gallwitz B. Gastric inhibitory polypeptide: the neglected incretin revisited. Regul Pep 2002;107:1-13.

12. Nauck MA, Bartels E, Orskov C, Ebert R, Creutzfeldt W. Lack of effect of synthetic human gastric inhibitory polypeptide and glucagon-like peptide 1 [7-36 amide] infused at near-physiological concentrations on pentagastrin-stimulated gastric acid secretion in normal human subjects. Digestion 1992;52:214-21.

13. Dupre J, Ross SA, Watson D, Brown JC. Stimulation of insulin secretion by gastric inhibitory polypeptide in man. J Clin Endocrinol Metab 1973;37:826-8.

14. Andersen DK, Elahi D, Brown JC, Tobin JD, Andres R. Oral glucose augmentation of insulin secretion. Interactions of gastric inhibitory polypeptide with ambient glucose and insulin levels. J Clin Invest 1978;62:152-61.

15. Lewis JT, Dayanandan B, Habener JF, Kieffer TJ. Glucose-dependent insulinotropic polypeptide confers early phase insulin release to oral glucose in rats: demonstration by a receptor antagonist. Endocrinology 2000;141:37106.

16. Tseng CC, Zhang XY, Wolfe MM. Effect of GIP and GLP-1 antagonists on insulin release in the rat. Am J Physiol 1999;276:1049-54.

17. Elahi D, Andersen DK, Brown JC, Debas HT, Hershcopf RJ, Raizes GS, et al. Pancreatic alpha- and beta-cell responses to GIP infusion in normal man. Am J Physiol 1979;237:185-91.

18. Ehses JA, Casilla VR, Doty T, Pospisilik JA, Winter KD, Demuth HU, et al. Glucose-dependent insulinotropic polypeptide promotes beta- (INS-1) cell survival via cyclic adenosine monophosphate-mediated caspase-3 inhibition and regulation of p38 mitogen-activated protein kinase. Endocrinology 2003;144:4433-45.

19. Trumper A, Trumper K, Horsch D. Mechanisms of mitogenic and anti-apoptotic signaling by glucose-dependent insulinotropic polypeptide in beta (INS-1)-cells. J Endocrinol 2003;174:233-46.

20. Trumper A, Trumper K, Trusheim H, Arnold R, Goke B, Horsch D. Glucosedependent insulinotropic polypeptide is a growth factor for beta (INS-1) cells by pleiotropic signaling. Mol Endocrinol 2001;15:1559-70.

21. Drucker DJ. Enhancing incretin action for the treatment of type 2 diabetes mellitus. Diabetes Care 2003;26:2929-40.

22. Vilsboll T, Krarup T, Deacon CF, Madsbad S, Holst JJ. Reduced postprandial concentrations of intact biologically active glucagon-like peptide 1 in type 2 diabetic patients. Diabetes 2001:50:609-13.

23. Nauck MA, Heimesaat MM, Orskov C, Holst JJ, Ebert R, Creutzfeldt W. Preserved incretin activity of glucagon-like peptide-1 (7-36amide), but not of synthetic human gastric inhibitory polypeptide in patients with type 2 diabetes mellitus. J Clin Invest 1993;91:301-7.

24. Vilsboll T, Knop FK, Krarup T, Johansen A, Madsbad S, Larsen S, et al. The pathophysiology of diabetes involves a defective amplification of the late-phase insulin response to glucose by glucose-dependent insulinotropic polypeptide - regardless of etiology and phenotype. J Clin Endocrinol Metab 2003; 88:4897-903.

25. Yip RG, Wolfe MM. GIP biology and fat metabolism. Life Sci 2000;66:91-103.

26. Meier JJ,Nauck MA. GIP as a potential therapeutic agent? Horm Metab Res 2004;36;859-66.

27. Aroda VR, Henry RR. Incretin Hormones in Diabetes and Metabolism. [Accessed on 2005 Jul 30]. Available from: www.medscape.com/viewpoint/ 3075_pnt.

28. Bell Gl, Sanchez-Pescador R, Laybourn PJ, Najarian RC. Exon duplication and divergence in the human preproglucagon gene. Nature 1983;304:368-71.

29. Glucagon.com [homepage on the internet]. Toronto General Hospital, Banting and Best Diabetes Centre, University of Toronto. [Accessed on 2005 Sep 28]. 
Available from: http://www.glucagon.com/glp-1 receptor.htm

30. Herrmann C, Goke R, Richter G, Fehmann HC, Arnold R, Goke B. Glucagonlike peptide-1 and glucose-dependent insulin-releasing polypeptide plasma levels in response to nutrients. Digestion 1995;56:117-26.

31. Orskov C, Wettergren A, Holst JJ. Secretion of the incretin hormones glucagon-like peptide-1 and gastric inhibitory polypeptide correlates with insulin secretion in normal man throughout the day. Scand J Gastroenterol 1996;31:665-70

32. Vilsboll T, Agerso H, Krarup T, Holst JJ. Similar elimination rates of glucagonlike peptide-1 in obese type 2 diabetic patients and healthy subjects. J Clin Endocrinol Metab 2003:88:220-4

33. Matsuyama T, Komatsu R, Namba M, Watanabe N, Itoh H, Tarui S. Glucagonlike peptide-1 (7-36 amide): a potent glucagonostatic and insulinotropic hormone. Diabetes Res Clin Pract 1988;5:281-4.

34. Wang Y, Perfetti R, Greig N H, Holloway HW, De Ore KA, Montrose-Rafizadehc $\mathrm{C}$, et al. Glucagon-like peptide-1 can reverse the age-related decline in glucose tolerance in rats. J Clin Invest1997;99:2883-9.

35. Perfetti R, Zhou J, Doyle ME, Egan JM. GLP-1 induces cell proliferation, PDX1 expression and increases endocrine cell mass in the pancreas of old, glucose-intolerant rats. Endocrinology 2001;141:4600-5.

36. Hui H, Wright C, Perfetti R. Glucagon-like-peptide-1 induces differentiation of islet-duodenal homeobox-1- positive pancreatic ductal cells into insulin-secreting cells. Diabetes 2001;50:785-96.

37. Farilla L, Hui H, Bertolotto C, Kang E, Bulotta A, Di Mario U, et al. Glucagonlike Peptide-1 promotes islet cell growth and inhibits apoptosis in zucker diabetic rats. Endocrinology 2002;143:4397-408.

38. Farilla L, Bulotta A, Hirshberg B, Li Calzi S, Khoury N, Noushmehr H, et al. Glucagon-like peptide 1 inhibits cell apoptosis and improves glucose responsiveness of freshly isolated human islets. Endocrinology 2003;144:5149-58.

39. Meeran K, O'Shea D, Edwards CM, Turton MD, Heath MM, Gunn I, et al. Repeated intracerebroventricular administration of glucagon-like peptide-1-(7-36) amide or exendin-(9-39) alters body weight in the rat. Endocrinology 1999:140:244-50.

40. Schick RR, Zimmermann JP, vorm Walde T, Schusdziarra V. Peptides that regulate food intake: Glucagon-like peptide 1-(7-36) amide acts at lateral and medial hypothalamic sites to suppress feeding in rats. Am J Physiol Regul Integr Comp Physiol 2003;284:1427-35.

41. Verdich C, Flint A, Gutzwiller JP, Naslund E, Beglinger C, Hellstorm PM, et al. A meta-analysis of the effect of glucagon-like peptide-1 (7-36) amide on ad libitum energy intake in humans. J Clin Endocrinol Metab 2001:86:4382-9.

42. Gutzwiller JP, Drewe J, Goke B, Schmidt H, Rohrer JE, Larieda J, et al. Glucagon-like peptide-1 promotes satiety and reduces food intake in patients with diabetes mellitus type 2 d. Am J Physiol 1999;276:1541-4.

43. Toft-Nielsen MB, Madsbad S, Holst JJ. Continuous subcutaneous infusion of glucagons-like peptide 1 lowers plasma glucose and reduces appetite in type 2 diabetic patients. Diabetes Care 1999;22:1137-43.

44. Naslund E, Barkeling B, King N, Gutnaik M, Blundell JE Holsst JJ, et al. Energy intake and appetite are suppressed by glucagons-like peptide-1 (GLP-1) in obese men. Int J Obes Relat Metab Disord 1999;23:304-11.

45. Long SJ, Sutton JA, Amaee WB, Giouvanoudi A, Spyrou NM, Rogers PJ, et al. No effect of glucagons-like peptide-1 on short-term satiety and energy intake in man. Br J Nutr 1999;81:273-9.

46. Zander M, Madsbad S, Madsen JL, Holst JJ. Effect of 6-week course of glucagons-like peptide 1 on glycemic control, insulin sensitivity, and beta-cell function in type 2 diabetes: A parallel-group study. Lancet 2002;359:824-30.

47. Bloomgarden ZT.Gut-Derived incretin hormones and new therapeutic approaches.Diabetes Care 2004;27:2554-9.

48. Gutniak M, Orskov C, Holst JJ, Ahren B, Efendic S. Antidiabetogenic effect of glucagon-like peptide-1 (7-36) amide in normal subjects and patients with diabetes mellitus. N Engl J Med 1992;326:1316-22.

49. Nauck MA, Bartels E, Orskov C, Ebert R, Creutzfeldt W. Additive insulinotropic effects of exogenous synthetic human gastric inhibitory polypeptide and glucagon-like peptide-1-(7-36) amide infused at near-physiological insulinotropic hormone and glucose concentrations. J Clin Endocrinol Metab 1993;76: 912-7.

50. Preitner F, Ibberson M, Franklin I, Binnert C, Pende M, Gjinovci A, et al. Glucoincretins control insulin secretion at multiple levels as revealed in mice lacking GLP-1 and GIP receptors. J Clin Invest 2004;113:635-45.

51. Hansotia T, Baggio L, Delmeire D, Hinke SA, Yamada Y, Tsukiyama K, et al. Double incretin receptor knockout (DIRKO) mice reveal an essential role for the enteroinsular axis in transducing the glucoregulatory action of DPP-IV inhibitors. Diabetes 2004;53:1326-35.

52. Holst JJ, Orskov C. The incretin approach for diabetes treatment: Modulation of islet hormone release by GLP-1 agonism. Diabetes 2004;53:197-204.

53. Deacon DF, Nauck MA, Meier JJ, Hucking K, Holst JJ. Degradation of endogenous and exogenous gastric inhibitory polypeptide (GIP) in healthy and in type 2 diabetic subjects as revealed using a new assay for the intact peptide. J Clin Endocrinol Metab 2000;85:3575-81.

54. O'Harte FP, Mooney MH, Kelly CM, Flatt PR. Improved glycemic control in obese diabetic ob/ob mice using N-terminally modified gastric inhibitory polypeptide. J Endocrinol 2000;165:639-48.

55. O'Harte FP, Gault VA, Parker JC, Harriott P, Mooney MH, Bailey CJ, et al. Improved stability, insulin-releasing activity and antidiabetic potential of two novel N-terminal analogues of gastric inhibitory polypeptide: N-acetyl-GIP and pGlu-GIP. Diabetologia 2002;45:1281-91.

56. Hinke SA, Gelling RW, Pederson RA, Manhart S, Nian C, Demuth HU, et al. Dipeptidyl peptidase IV-resistant [D-Ala(2)]glucose-dependent insulinotropic polypeptide (GIP) improves glucose tolerance in normal and obese diabetic rats. Diabetes 2002;51:652-61

57. Meier JJ, Gallwitz B, Kask B, Deacon CF, Holst JJ, Schmidt WE, et al Stimulation of insulin secretion by intravenous bolus injection and continuous infusion of gastric inhibitory polypeptide in patients with type 2 diabetes and healthy control subjects. Diabetes 2004;53:220-4.

58. Gault VA, Flatt PR, Bailey CJ, Harriott P, Greer B, Mooney MH, et al. Enhanced cyclic AMP generation and insulin-releasing potency of two novel $\mathrm{N}$ terminal Tyr1-modified enzyme resistant forms of GIP, is associated with significant antihyperglycemic activity in spontaneous obesity-diabetes. Biochem J 2002;367:913-20.

59. Irwin N, Green BD, Mooney MH, Greer B, Harriott P, Bailey CJ, et al. A novel, long-acting agonist of glucose dependent insulinotropic polypeptide (GIP) suitable for once daily administration in type 2 diabetes. J Pharmacol Exp Ther 2005;314;1187-94.

60. Gutniak MK, Linde B, Holst JJ, Efendic S. Subcutaneous injection of the incretin hormone glucagon-like peptide 1 abolishes postprandial glycemia in NIDDM. Diabetes Care1994;17:1039-44.

61. Eng J, Kleinman WA, Singh L, Singh G, Raufman JP. Isolation and characterization of exendin 4, an exendin 3 analogue from Heloderma suspectum venom. J Biol Chem 1992:267:7402-5.

62. Chen YE, Drucker DJ. Tissue-specific expression of unique mRNAs that encode proglucagon-derived peptides or exendin 4 in the lizard. J Biol Chem 1997;272:4108-115.

63. WaknineY. Medscape Medical News, FDAApprovals: Boostrix, Byetta, Kaletra [last accessed November 2005]. Available from: www.medscape.com/ viewarticle/504372

64. Fineman MS, Bicsak TA, Shen LZ, Taylor K, Gainess E, Varns A, et al. Effect on glycemic control of exenatide (synthetic exendin-4) additive to existing metformin and/or sulfonylurea treatment in patients with type 2 diabetes. Diabetes Care 2003;26:2370-7.

65. Kolterman OG, Buse JB, Fineman MS, Gaines E, Heintz S, Bicsak TA, et al. Synthetic exendin-4 (exenatide) significantly reduces postprandial and fasting plasma glucose in subjects with type 2 diabetes. J Clin Endocrinol Metab 2003:88:3082-9

66. DeFronzo RA, Ratner RE, Han J, Kim DD, Fineman MS, Baron AD. Effects of exenatide (exendin-4) on glycemic control and weight over 30 weeks in metformin-treated patients with type 2 diabetes. Diabetes Care 2005;28:1092100.

67. Kendall DM, Riddle MC, Rosenstock J, Zhuang D, Kim DD, Fineman MS, et al. Effects of exenatide (exendin-4) on glycemic control over 30 weeks in patients with type 2 diabetes treated with metformin and a sulfonylurea. Diabetes Care 2005;28:1083-91.

68. Fineman MS, Shen LZ, Taylor K, Kim DD, Baron AD. Effectiveness of progressive dose-escalation of exenatide (exendin-4) in reducing dose-limiting side effects in subjects with type 2 diabetes. Diabetes Metab Res Rev 2004;20: 411-7.

69. Gedulin BR, Smith P, Prickett KS, Tryon M, Barnhill S, Reynolds J, et al. Doseresponse for glycaemic and metabolic changes 28 days after single injection of long-acting release exenatide in diabetic fatty Zucker rats. Diabetologia 2005;48:1380-5

70. Knudsen LB, Nielsen PF, Huusfeldt PO, Johansen NL, Madsen K, Pedersen $\mathrm{FZ}$, et al. Potent derivatives of glucagon-like peptide-1 with pharmacokinetic 
properties suitable for once daily administration. J Med Chem 2000;43: 1664-9.

71. Degn KB, Juhl CB, Sturis J, Jakobsen G, Brock B, Chandramouli V, et al. One week's treatment with the long-acting glucagon-like peptide 1 derivative liraglutide (NN2211) markedly improves 24-h glycemia and ß-cell function and reduces endogenous glucose release in patients with type 2 diabetes. Diabetes 2004;53:1187-94.

72. Elbrond B, Jakobsen G, Larsen S, Agerso H, Jensen LB, Rolan P, et al. Pharmacokinetics, pharmacodynamics, safety, and tolerability of a single-dose of NN2211, a long-acting glucagon-like peptide 1 derivative, in healthy male subjects. Diabetes Care 2002;25:1398-404.

73. Kim JG, Baggio LL, Bridon DP, Castaigne JP, Robitaille MF, Jette L, et al. Development and characterization of a glucagon-like peptide 1-albumin conjugate: the ability to activate the glucagon-like peptide 1 receptor in vivo. Diabetes 2003;52:751-9.

74. Giannoukakis N. CJC-1131. Conju Chem. Curr Opin Investig Drugs 2003;4:1245-9.

75. Baggio LL, Huang Q, Brown TJ, Drucker DJ. A recombinant human glucagonlike peptide (GLP)-1-albumin protein (albugon) mimics peptidergic activation of GLP-1 receptor-dependent pathways coupled with satiety, gastrointestinal motility, and glucose homeostasis. Diabetes 2004;53:2492-500.

76. Deacon CF, Wamberg S, Bie P, Hughes TE, Holst JJ. Preservation of active incretin hormones by inhibition of dipeptidyl peptidase IV suppresses mealinduced incretin secretion in dogs. J Endocrinol 2002;172:355-62.
77. Ahren B, Simonsson E, Larsson H, Landin-Olsson M, Torgeirsson H, Jansson $\mathrm{PA}$, et al. Inhibition of dipeptidyl peptidase IV improves metabolic control over a 4-week study period in type 2 diabetes. Diabetes Care 2002;25:869-75.

78. Mari A, Sallas WM, He YL, Watson C, Igueros-Saylan M, Dunning BE, et al. Vildagliptin a dipeptidyl peptidase-IV inhibitor, improves model: Assessment (beta)-cell function in patients with type 2 diabetes. J Clin Endocrinol Metab 2005:90:4888-94.

79. Kim D, Wang L, Beconi M, Eiermann GJ, Fisher MH, He H, et al. (2R)-4-oxo4-[3-(trifluoromethyl)-5,6-dihydro[1,2,4]triazolo[4,3-a]pyrazin-7(8H) -yl]-1-(2,4,5trifluorophenyl)butan-2-amine: a potent, orally active dipeptidyl peptidase IV inhibitor for the treatment of type 2 diabetes. J Med Chem 2005;48:141-51.

80. Lindsay JR, Duffy NA, McKillop AM, Ardill J, O'Harte FP, Flatt PR, et al. Inhibition of dipeptidyl peptidase IV activity by oral metformin in type-2 diabetes. Diabet Med 2005;22:654-7.

81. Drucker DJ. Therapeutic potential of dipeptidyl peptidase IV inhibitors for the treatment of type 2 diabetes. Expert Opin Investig Drugs 2003;12:87-100.

82. Gorrell MD, Gysbers V, McCaughan GW. CD26: a multifunctional integral membrane and secreted protein of activated lymphocytes. Scand J Immunol 2001;54:249-64

83. Yan S, Marguet D, Dobers J, Reutter W, Fan H. Deficiency of CD26 results in a change of cytokine and immunoglobulin secretion after stimulation by pokeweed mitogen. Eur J Immunol 2003;33:1519-27.

84. Mentlein R. Therapeutic assessment of glucagon-like peptide-1 agonists compared with dipeptidyl peptidase IV inhibitors as potential antidiabetic drugs. Expert Opin Investig Drugs 2005;14:57-64.

\section{GenXPharm}

\section{The newest e-group for the next generation pharmacologists}

Have a problem with your study design?

Looking for particular references?

Need a special chemical?

Want to know which statistical test to use?

Whatever your problem may be - you are not alone

Come share your thoughts, views and ideas with young pharmacologists all over India

Get help, information and support from your peers

Join GenXPharm - the e-group with pizzaz

This forum is for postgraduate students and research scholars only

For further information please contact:

\section{Dr. S. Manikandan}

Department of Pharmacology, JIPMER, Pondicherry-605 006.

E-mail: manikandan001@yahoo.com 